\title{
STYRING MED STRAF
}

\section{AF PROFESSOR, DR. JUR. KNUD WAABEN}

After a brief presentation of traditional theories on the aim of punishment, the paper presents some views on the effectiveness of penal sanctions as a means of preventing offenders from committing further offences. As an illustration, an outline is given of community service as applied in Danish law since 1982. Recent legislation has extended this measure to the offence of drunken driving. *

Jeg blev lidt betænkelig da jeg så det opgivne emne: "Styring med straf". Meningen måtte jo være at det her drejede sig om at styre borgerne uden om kriminalitet og straf, dels ved at true med straf, dels ved faktisk at straffe når truslen ikke har virket. Og efter alt hvad jeg har læst mig til er vi meget langt fra at kunne styre borgerne på den måde. Jeg kan heller ikke tilbyde en indledning som bringer os nærmere til målet. Styring er et stærkt ord. Den er af vital betydning til søs og på gader og veje. Myndighederne kan, når de har en heldig hånd, styre deres budgetter og deres sundheds- og fængselsvæsen og fordelingen af skattebyrden. Men at styre borgerne til lovlydighed gennem straffesystemet er noget ganske andet.

$\mathrm{Nu}$ ved jeg godt at det på mange særlovsområder lykkes meget godt at få borgerne til at gøre hvad der bliver sagt. Det er næppe særlove og forseelser det her skal handle om; alligevel kan det jo godt markeres at også dette hører til faget. Noget af det første jeg lærte, da jeg begyndte at læse strafferet under krigen, var dette: at straffetruslen kunne få alle til at mørklægge på klokkeslet og få hundrede tusinder eller flere til at sørge for lygte, katteøje og klokke på cyklerne. Men jeg lærte også et par år senere at når politiet fjernes stiger kriminaliteten i rask tempo. Det må minde os om at kontrol er lige så vigtig som lovens straffetrussel og de pålagte straffe. Når vi overvejer en kriminalisering, må vi derfor også tage stilling til det spørgsmål, om vi ønsker denne kontrol. Men der kan også af og til være grund til at spørge om kontrol og håndhævelse overhovedet er mulig. Betydningen af overvågning kan jeg tale med om af egen erfaring. Jeg var to gange blevet grebet $\mathrm{i}$ at køre $\mathrm{i}$ bil uden at bruge sikkerhedsselen, og havde fået to bøder på hver 200 kr., før jeg lærte at efterleve den regel. Myndighederne kan altså godt styre mig, men det går bedst hvis de holder mig under opsigt.

Denne bekendelse ville jeg næppe være kommet frem med, hvis det havde drejet sig om butikstyverier. Der er forskel på mala in se, det i sig selv slette, og

Den mundtlige indledning på kriminalistmødet gengives her med nogle tilføjelser, som hist og her lader informationer og synspunkter træde tydeligere frem. Alligevel vil det ses at der kun er tale om strejflys over et emne som spænder vidt.

* Title in English: Behaviour Control throngh Punishment. Original in Danish. 
mala prohibita, det blot forbudte. Når jeg her begynder at tale latin, er det for at forberede forsamlingen på lidt om straffeteorier. Jeg lover at det ikke vil blive slemt.

Vi er gået ind i et nyt årtusinde uden alvorlige sammenbrud i vore livsværdier (det er computerne jeg sigter til). Og det kan vel ikke skade at vi i vore kredse genopfrisker hvad de gamle har sagt om straffens formål og virkninger. Det er ca. 2000 år siden Cicero ytrede de berømte ord: at man kan straffe enten fordi der er fejlet, quia peccatum est, eller for at der ikke skal fejles (igen), ne peccetur. Grækerne havde i øvrigt sagt det samme. Vi er altså på klassisk grund, og her kan jeg tage mit udgangspunkt. En række tanker om strafformål vil jeg dog kun lade passere forbi $i$ hast.

Vi kan se bort fra straf quia peccatum est. Det drejer sig her groft sagt om to filosofiske tankegange der ikke har noget med styring at gøre: at den moralske verdensorden opretholdes når man gengælder ondt med ondt, eller at statens autoritet opretholdes når man markerer at ulydighed mod statens bud ikke tolereres. Kant sagde: Om så verden ville gå under derved, ville det være vor pligt at fuldbyrde den sidste dødsstraf. Den danske jurist F. C. Bornemann sagde: Om så samfundsmoralen blev så høj at staten ikke behøvede straffen for at beskytte sig, måtte retfærdighedsidéen i statsstyret alligevel påbyde straf.

Jeg vil også se bort fra det som vi kalder de almenpræventive virkninger: de afskrækkende, advarende og holdningsstyrkende sider af systemet. Alt dette er langtfra betydningsløst, men det ville let få mig til at bruge tiden på et causeri ud i tågen.

Endelig kommer jeg ikke ind på den umiddelbare styring ved indespærring, med et fint ord: inkapacitering. Jeg har det indtryk at det er en gevinst som af og til undervurderes. På den anden side befinder vi os her i det dilemma at vi i de nordiske lande ønsker os et lavt niveau af udmålte frihedsstraffe. Inkapaciteringen må ikke bruges som et almindeligt argument mod dette velbegrundede ønske om et lavt straffeniveau. Problemet hører altså til den grove og persistente kriminalitet. Her ytrer det sig bl.a. i regler om forvaring, desuden i de straffe for narkotikahandel som skal drøftes i morgen. I Danmark har væsentlig risiko for tilbagefald i stigende grad været en grund til at nægte prøveløsladelse fra lukkede anstalter efter den normale to trediedels termin. ${ }^{1}$

Her vil jeg koncentrere mig om styring med straf $i$ en sncever mening. Kan vi vælge vore straffemidlers art og kvantum på en sådan måde at vi med størst sandsynlighed opnår en nyttig effekt hos dem som vi straffer?

Da vi forrige gang passerede et århundredskifte, år 1900, var mange i Europa optaget af en smuk drøm de havde haft. Det var drømmen om at kriminelle tilbøjeligheder kan fjernes ved en manipulation der tager sit udgangspunkt $i$ ejendommeligheder ved individet og dets situation. Hvis vi vil bevare noget af den drøm, og gøre den til mere end en drøm, må vi handle i overensstemmelse med 
en reel viden om individerne og vore muligheder for at have indflydelse på deres skæbne.

Ved samme tid, omkring år 1900, havde disse rebeller da også en anden drøm, som i og for sig var meget logisk (hvis drømme ellers kan være logiske, - mine er det ikke). De ønskede sig en videnskab der kunne kaldes kriminologi, et navn der vistnok først var blevet kendt i forbindelse med kriminalstatistiske opgørelser i Belgien og Frankrig. Denne forskning skulle forsyne lovgivere og jurister med viden om de kriminelles egenskaber og de retlige midlers egnethed. Uheldigvis var mange af den tids bidrag ikke brugbare. Det gjaldt især de biologiske skoler - antropologi og psykiatri - der skildrede arveanlæg (det degenererede individ) og fysiske særtræk (den fødte forbryder). ${ }^{2}$

Senere fulgte den kriminologi som vi har kendt og kender i de nordiske lande, specielt i dens læreforhold til USA og England. Den har været sociologisk orienteret $\mathrm{og}$ arbejdet på mere frugtbar mark end dens biologiske forgængere. Men jeg er i stigende grad kommet i tvivl, om markens grøde har svaret til forventningerne, forskningsmæssigt og kriminalpolitisk. Engang ventede jeg vel at strafferetten og kriminologien ville komme til at spille sammen i en double mod den formidable modstander på den anden side af nettet. Sådan gik det ikke. De fleste jurister læser ikke andet end de lovkommentarer og domssamlinger som er deres fast food. De fleste kriminologer læser ikke strafferet og tilegner sig ikke de historiske, analytiske og praktiske problemformuleringer som er juraens domæne. Dette skal ikke være et angreb på kriminologiens akademiske status eller anfægte dens ret til selv at vælge sine opgaver, hvad enten de fører til hårdt arbejde eller går i retning af samfundsfilosofiens Utopia. Men jeg hælder til den opfattelse, at hvis strafferetten vil have svar på de spørgsmål den sidder med, da må kriminologerne knyttes direkte til det retlige system, navnlig det lovforberedende og det fuldbyrdende, således som vi jo også kender det. Nogle opgaver må stilles af dem der har brug for hjælp; det er for en stor del statistiske opgaver, men ikke kun en sløvt registrerende talindsamling. Om bestilte resultater er der naturligvis ikke tale.

Hvad angår den strafferetlige udvikling vil jeg kun afrunde hvad der blev sagt med startpunkt i år 1900. Måske vil historiens dom engang blive at der i løbet af 1900-tallet indtrådte tre, fire eller fem væsentlige nydannelser i straffesystemet: indførelsen af betingede domme og tiltalefrafald (opportunitetsprincippet, især accepteret i Norge og Danmark), indførelsen af åbne anstalter i kriminalforsorgen og sidst indførelsen af samfundstjeneste. Alt dette har været vendt mod en overleveret strenghed. Man kunne nok med forsigtighed tilføje endnu et træk: den gradvise reduktion af niveau'et på vide områder af strafudmålingen. Intet af det som jeg har nævnt er et resultat af forskning. Det har sin rod i en common sense, der bl.a. er styret af en moralsk klimaforbedring i relation til frihedsberøvelsen. 
Jeg nævnte samfundstjenesten. Måske kunne vore styringsproblemer belyses mere konkret og aktuelt, hvis jeg opholdt mig lidt ved samfundstjenesten. Den kan ses som en sen aflægger af den forsorg i frihed som blev indført i dansk lovgivning i 1905. Så vidt jeg husker var der ikke tilsyn i de første norske og svenske regler om betingede domme. Samfundstjenesten er også beslægtet med forsorg i frihed på den måde at der i begge henseender er tale om lægfolks deltagelse i straffuldbyrdelsen. Den oprindelige frie forsorg var i høj grad baseret på tilsyn udført af privatpersoner med hjertet på det rette sted. I samfundstjenesten er der egentlig et stærkt reduceret element af traditionel forsorg i frihed. Det centrale træk er at et af samfundets normalmiljøer modtager den dømte og så at sige fuldbyrder dommen. Her modarbejdes den konfliktbetonede fremmedgørelse af retssystemet. Men det sker under kontrol fra en tilsynsinstans, der uundgåeligt får den opgave også at repræsentere den egentlige straffetrussel: risikoen for indberetning og frihedsstraf. Jeg må ubetinget se større muligheder i samfundstjenestens metode end $i$ et møde mellem gerningsmand og offer.

For godt 25 år siden begyndte man i de nordiske lande at drøfte det som på engelsk kaldes community service. Der kom i vore lande nogle dengang meget omtalte betænkninger som berørte denne samfundstjeneste. ${ }^{3}$ Det viste sig fra første færd at der var to forskellige holdninger til tanken, og det blev bekræftet da Nordisk Strafferetskomité i 1980 afgav en betænkning om alternativer til frihedsstraf. ${ }^{4}$ Alle var ganske vist enige om at forsøgsordninger ville bringe større klarhed over samfundstjenestens muligheder. Men ellers var det tydeligt at der i danske og norske indlæg - jeg tror også i islandske - var en positiv holdning til tanken, men fra finsk og svensk side nogen skepsis. Den skeptiske bedømmelse blev især begrundet med en ulyst ved at anvende arbejdspligt som straf samt en frygt for social skævhed og for en praksis der ikke gjorde indhug i frihedsstraffene, men snarere var en skærpelse af de retsfølger der ellers ville blive idømt. Der var også en tvivl om de praktiske muligheder for at skaffe arbejdspladser som ikke hørte til det almindelige arbejdsmarked, altså lønmodtagernes område.

Undertiden indgik der vist også i meningsudvekslingen den opfattelse at sanktionssystemet ikke bør rumme for mange muligheder. Når det gjaldt vurderingen af alternativer til frihedsstraf var der i nogle lejre præferencer som foreløbig udkonkurrerede samfundstjenesten: "anmälningsplikt", "straffvarning", "intensivövervakning" mv.

Jeg kan her lade alle argumenter og alle mellemstadier hvile i historiens mørke. Det er et mørke som forbavsende hurtigt opsluger store dele af den kriminalpolitiske litteratur. Afgørende er det i min sammenhæng at vi fik forsøgsordninger og derefter ny lovgivning.

Den første forsøgsordning var den danske. ${ }^{6}$ Da den havde løbet i seks år blev der foretaget nogle opgørelser af resultaterne. Jeg vil nævne et par af de vigtigste tal.

(1) $80 \%$ af de dømte gennemførte deres samfundstjeneste med det udmålte 
timeantal, mindst 40 og højst 240 timer. $20 \%$ fik forløbet afbrudt, enten på grund af vilkårsovertrædelser - typisk gentagen udeblivelse fra det anviste arbejde - eller på grund af ny kriminalitet.

Det var vigtigt i første omgang at konstatere at der kunne skaffes arbejdspladser, og at fire ud af hver fem domfældte kunne gennemføre deres arbejdspligt. Disse to forhold var jo prøven på om en ny retlig reaktion overhovedet kunne praktiseres. Derfor hed det en forsøgsordning i de første 10 år. Samtidig blev det slået fast at den velkendte personundersøgelse fik en ny mening. Her anlægges jo en prognose, som ganske vist kan kaldes kortsigtet, men dog påvirker domstolenes villighed til at give afkald på frihedsstraffen.

(2) En recidivundersøgelse under forsøgsordningen omfattede 700 personer. Den viste at $25 \%$ af de dømte i løbet af 2 år fra dommen fik en ubetinget frihedsstraf eller en betinget dom for ny kriminalitet. På den anden side var der $75 \%$ som klarede 2 år uden en sådan dom. To senere opgørelser omfattede hver kun én domsårgang. I den ene lå recidivet lidt over de $25 \%$, i den anden lidt under. $\left.{ }^{7}\right)$

De tal jeg her har nævnt ser jo godt ud, men strengt taget er de ikke et bevis for at der er anvendt et middel der er mere effektivt end andre. De der får samfundstjeneste er jo en udvalgt skare, som måske under alle omstændigheder ville have klaret sig godt.

Hvis nogen ville forsøge sig med en slags bevisførelse, måtte der nok gennemføres en af de effektundersøgelser hvor man sammenligner recidivet $i$ to grupper af domfældte, der har været undergivet forskellige sanktioner eller forskellige former for straffuldbyrdelse. Disse undersøgelser blev der foretaget en del af for nogle årtier siden, skønt vist ikke tilstrækkelig mange i de nordiske lande. Jeg vil trække dem frem af glemslen - hvis det er dér de befinder sig - fordi de kunne fortjene en ny stimulans og i hvert fald en ny debat om deres brugbarhed. De har i hvert fald den gode side at vise en koncentreret opmærksomhed for hvem de domfældte er og hvad man har gjort ved dem. Emnet har en nær sammenhæng med visse kriminalpolitiske principdrøftelser: Skal vort system drives langt $\mathrm{i}$ retning af de på lighed, proportionalitet og forudselighed funderede valg mellem nogle få sanktionsmuligheder, en enkel skala der kan måle hvad svenskernes kalder handlingers "straffvärde"? Det bekræftende svar herpå er for mig at se en holdning der har kulmineret. Eller kan vi finde det forsvarligt og nyttigt at råde over nye midler med en bevist eller sandsynlig eller blot mulig brugbarhed og en tilstrækkelig appel til domstolenes eller administratorernes villighed? Som nogle véd, opfordrer vore venner i Canada os stærkt til ikke at miste troen på at opfindsomhed og målrettet arbejde nytter noget.

Hvad angår de komparative sanktionsundersøgelser er der nok andre der har mere at bidrage med end jeg. Men jeg kan i hvert fald understrege at undersøgelserne er behæftet med en stor vanskelighed. Man skal udvælge grupper der 
er sammenlignelige $\mathrm{i}$ henseende til faktorer som alder, forstraffe, kriminalitetsart mv. ${ }^{8}$ Det som man sammenligner er i første række det kriminelle recidiv. Med rette er det blevet fremhævet at der også er andre målestokke for en effekt, fx en øget social stabilitet trods et indtruffet recidiv, eller omvendt social forringelse hvor kriminelle udslag ikke er konstateret. ${ }^{9}$ Dette er vistnok virkninger som kun de mest forfinede metoder kan opfange.

Nogle har været fristet til den generalisering at alle strafmidler stort set vil føre til samme resultat. Men undersøgelserne har geografisk set ligget meget spredt, mange langt fra os, og de har drejet sig om meget forskellige persongrupper og meget forskellige sanktioner.

Det burde ikke være overraskende at alle midler kan komme til kort over for dem der frembyder de største sociale og personlighedsmæssige problemer. Der er andre grupper som man endnu kan gøre sig håb om at nå ved veludførte initiativer. En analogi fra lægeverdenen er nærliggende: Hvor dybt sidder defekten? Hvad kan vi nå med vore medikamenter og instrumenter? Er vore valg af betydning når forløbet efter alt at dømme er irreversibelt? Nogle af de forgængere som jeg nævnte, generationen omkring år 1900, var nærmere ved denne analogi end vi er. Der er i dag nogle som mener at straffens udmålingsprincip bør overføres til dem der mest udtalt behøver psykiatrisk behandling.

I 1950'erne bemærkede mange en undersøgelse foretaget af Karl O. Christiansen og Karen Berntsen. ${ }^{10}$ Et tilfældigt udvalg af korttidsafsonere i Københavns fængsler blev genstand for en særlig intens psykologisk og forsorgsmæssig opmærksomhed. Jeg vil tro at mange af disse afsonere i dag ville have fået samfundstjeneste, og i hvert fald ville de normalt være kommet til et åbent fængsel. Efter en årrække (mindst 6 år) kunne det konstateres at recidivet $\mathrm{i}$ eksperimentgruppen lå signifikant lavere end hos den normalgruppe som de blev sammenlignet med. ${ }^{11}$

Nogle år senere blev et lignende forsøg gjort i den store danske undersøgelse som vi kaldte Fordundersøgelsen på grund af dens sponsor. Denne gang var det ikke afsonere men unge lovovertrædere under tilsyn. En endelig rapport blev ikke publiceret, ${ }^{12}$ men jeg kan godt røbe at tilbagefaldsprocenterne ikke var opløftende. Måske var der så stærke negative kræfter i gang, at de unge mennesker i eksperimentgruppen ikke lod sig påvirke af dygtige psykologer og socialrådgivere. Vi ved også om samfundstjenesten at det er vanskeligst at holde recidivet nede hos de unge domfældte. ${ }^{13}$

Vi fik også i Danmark omkring 1970 en stor komparativ undersøgelse af psykopatforvarede og nogle tilgrænsende grupper. ${ }^{14}$ Det drejede sig om relativt svært belastede og personlighedsmæssigt mere eller mindre afvigende personer, altså et tungt klientel. Her fandt man ikke tal der tydede på en markant større effekt af den lægeligt ledede psykopatbehandling i forvaring. Dette medvirkede til at tidsubestemtheden blev afskaffet for flertallet af de karakterafvigende (de ikke personfarlige), - og det tror jeg at den ville være blevet under alle omstæn- 
digheder. Den lægeligt ledede særanstalt for karakterafvigende fængselsdømte i Herstedvester blev ikke opgivet.

Om samfundstjenestens mulige effektivitet kan der ikke fremlægges undersøgelser af den type jeg her har talt om. Jeg må nøjes med at opsummere nogle indtryk og nogle sandsynligheder.

Vi har set at danske domstole er villige til at begrænse antallet af frihedsstraffe, når de ser arbejdspligt og tilsyn som et alternativ der er tilstrækkelig tyngende og tilstrækkelig lovende.

Vi har også set at det er muligt at udvælge et betydeligt antal til denne retsfølge, - vel nu henved 1.000 årligt. Men det kræver en nøje bedømmelse af de sigtedes egnethed til at virke mellem andre mennesker. Dette er en balancekunst. Man må ikke holde sig for meget på den sikre side, men der må heller ikke tages for store risici.

Vi har endelig grund til at formode at det samlede kriminelle recidiv hos de samfundstjenestedømte kan holdes på et lavt niveau.

Det er ikke sandsynligt at frihedsstraffe i de samme tilfælde ville have ført til et tilsvarende gunstigt resultat. Og i hvert fald er frihedsstraffen blevet sparet. Dette er en virkning som man godt a priori kan notere på samfundstjenestens plusside.

Det er heller ikke sandsynligt at almindelige betingede domme ville have haft samme effekt, statistisk set, så at arbejdspligten kunne have været sparet. Men der befinder sig neden under samfundstjenestens område en stor og betydningsfuld gruppe af betinget dømte med tilsyn og ikke sjældent andre vilkår. Jeg ved ikke meget om denne gruppe, og det er et spørgsmål om andre ved tilstrækkeligt om den. Min fornemmelse er at man kan have grund til at vise øget opmærksomhed for tilsynets virkemåder og for systematisk kortlægning af personlige forhold og kriminalitetens art og baggrund.$^{15}$ Det drejer sig her om en gruppe som ikke i første række rejser spørgsmål om at indføre nye sanktioner i loven, for den betingede dom med tillægsvilkår er et flexibelt alternativ til frihedsstraf. Problemet er snarere: Har personundersøgelsen været grundig nok? Hvad har den peget på? Hvorledes skal kriminalforsorgen praktisere vilkårene?

Samfundstjenestens område har sine grænser. Hos os derhjemme taler myndighederne om et varsomhedsområde, men det betyder forskellige ting:

(a) Der er tilfælde hvor personundersøgelsen efterlader en betydelig tvivl om den sigtedes evne til at gennemføre samfundstjeneste. Her er varsomhed på sin plads.

(b) Varsomhed kan fra domstolenes synspunkt skyldes kriminalitetens relative grovhed. Man har dog vistnok set - ligesom ved almindelige betingede domme - at grænsen kan forskydes opad på grovhedsskalaen, fx med hensyn til underslæb og lignende vedrørende store beløb. Måske forholder det sig sådan at jo større beløb folk har tilegnet sig ved svig og uredelighed, desto mindre er risikoen for at de vil gøre det igen. Dette er ikke en påstand, men en opfordring til 
kriminologerne om at kaste sig over en problemstilling. Det kan tænkes at resultaterne ville sende et nyt lys over forholdet mellem proportionalitet og recidivrisiko, også ved den såkaldte økonomiske kriminalitet i erhvervslivet. Opskriften gælder ikke studiet af bankrøvere.

(c) Endelig er der en varsomhed som er ønsket af politikerne. Når de tilråder varsomhed eller rentud strenghed, kan man ikke altid være sikker på at det er ønsker der udspringer af klogskab. Det gælder bl.a. deres advarsler mod samfundstjeneste over for voldsmænd af almindelige typer. Voldsmænd nyder ingen politisk medfølelse. Der er næppe nogen vælgerforening hvor man ikke kunne få vedtaget en resolution om strengere straffe for vold. Politikeres bagland har indflydelse. Hvad samfundstjenesten angår var der under forsøgsordningen en klart større tilbøjelighed i Østre Landsrets end i Vestre Landsrets område til at anvende samfundstjeneste i sager om almindelig vold. Straffelovrådet fandt i 1990 ikke grund til at tage afstand fra den åbenhed over for anvendelsen af samfundstjeneste som havde vist sig i Østre Landsret. ${ }^{16}$

Til allersidst vil jeg nævne at dansk ret nu indfører samfundstjeneste som alternativ til frihedsstraf for spiritus- og promillekørsel (i det følgende kaldt spirituskørsel). ${ }^{17}$ Dette vil gælde alle de almindeligt kendte udmålingssatser mellem 10 og 60 dage. Som følge af mange straffes korthed nedsættes lovens minimum for antallet af arbejdstimer fra 40 til 30 . Helt foreløbigt regnes der med et muligt antal samfundstjeneste- domme over for spiritusbilister på omkring 2.000 årligt. Dette er også en tilnærmelsesvis målestok for det antal indsættelser til afsoning som fremtidig vil blive undgået.

Der har i 10 år været anvendt et andet middel til reduktion af det store antal korte frihedsstraffe for spirituskørsel, som ingen har været stolte af. Efter en forsøgsordning har spirituskørere med alkoholproblemer kunnet slippe for frihedsstraf, når de gik med til en kontrolleret alkoholistbehandling i mindst et år. ${ }^{18}$ Denne ordning har i de senere år fået tilslutning fra ca. 1.000 domfældte årligt. De første opgørelser viser at recidivet til ny spirituskørsel er lavere hos dem der indgik på behandling - især hos dem der gennemførte den - end hos afsonere $\mathrm{i}$ samme kategori. ${ }^{19}$ Ordningen vil blive opretholdt, dog med den ændring at afgørelsen ikke længere vil være en administrativ betinget strafudsættelse med efterfølgende benådning, men en betinget dom med behandlingsvilkår af samme indhold.

Denne betingede dom og dommen til samfundstjeneste (som i dansk ret også formelt er en betinget dom) vil herefter anvise to veje til indhug i de korte frihedsstraffes dominans på dette område. I begge retninger må det ventes at der regelmæssigt vil blive knyttet en tillægsbøde til afgørelsen. Ved afgrænsningen mellem de to retsfølger vil vilkåret om alkoholistbehandling som hidtil være aktuelt for spritbilister med alkoholproblemer; behandlingsvilkåret vil her være det primære valg. Den anden mulighed vil bero på egnetheden til at gennemføre 
samfundstjeneste, men denne egnethed må dog ventes hyppigt at være til stede, når det drejer sig om et beskedent antal arbejdstimer. Almindelig kriminalstatistik vil i løbet af et par år vise hvilket mønster sanktionspraksis falder til rette i.

Justitsministeren har i sit lovforslag så at sige gjort undskyldning for den langtfra ukendte fremgangsmåde, at der i lovforarbejderne angives en del retningslinier - til dels af takstmæssig karakter - for de nye reglers anvendelse. Dommerforeningen har i høringsfasen ikke i dette tilfælde villet ytre betænkelighed ved fremgangsmåden.

Alt dette er en anden historie som måske kunne fortjene at blive fortalt ved det næste nordiske kriminalistmøde.

\section{Noter:}

${ }^{1}$ Kriminalforsorgens Statistik 1998 s. 25.

${ }^{2}$ Om den tids retspolitiske programmer og tilløb til kriminologi se bl.a. Knud Waaben: Strafferettens almindelige del II, Sanktionslæren, 4. udg. 1999, s. 4 ff og samme forf.: Retspsykiatri og strafferet i historiens lys, 1997 , s. $86 \mathrm{ff}$ og $96 \mathrm{ff}$.

${ }^{3} 1$ Danmark: Alternativer til frihedsstraf, Betænkning nr. 806/1977, s. 86 ff, i Finland: Straffrättskommitténs betänkande I, 1978 s. 61, i Norge: Om kriminalpolitikken, Stortingsmelding nr. 104, 1977-78, s. 118 ff og 172, i Sverige: Nytt straffsystem, Brottsförebyggande rådets Rapport 1977:7 s. $384 \mathrm{ff}$.

${ }^{4}$ Alternativer til frihedsstraf, Nordisk utredningsserie $1980: 13$ s. 19 f og 32 f.

${ }^{s}$ Strafrättskommitténs betänkande I s. 48 f, Nytt straffsystem s. 153.

${ }^{6}$ Foruden den ovenfor nævnte betænkning fra 1977 anføres her Straffelovrådets betænkning om samfundstjeneste, Betænkning nr. 1211/1990 samt om lovreglerne af 1992 William Rentzmann \& Johan Reimann: Samfundstjeneste og ungdomskontrakter, 1994.

${ }^{7}$ Kriminalforsorgens Statistik 1998 s. 32 ff.

${ }^{8}$ Af litteraturen om effektundersøgelsernes metodik og perspektiver skal her kun nævnes Roger Hood \& Richard Sparks: Key Issues in Criminology, 197o, s. $171 \mathrm{ff}$ med henvisninger s. $247 \mathrm{ff}$.

${ }^{9} \mathrm{Se}$ fx Hood \& Sparks anf.st. s. $177 \mathrm{f}$.

${ }^{10}$ Karl O. Christiansen \& Karen Berntsen: Mandlige arresthusfanger i Københavns fængsler, 1955.

${ }^{11}$ Karl O. Christiansen \& Karen Berntsen i Scandinavian Studies in Criminology vol. 1, 1965, s. $35 \mathrm{ff}$.

${ }^{12}$ Karen Berntsen: Tilbud til stofmisbrugere, 1971, skildrer behandlingsarbejdet ved Ungdomsklinikken i København, navnlig efter Ford-undersøgelsens afslutning.

${ }^{13}$ Straffelovrådets betænkning om samfundstjeneste s. 32, Kriminalforsorgens Statistik 1998 s. $32 \mathrm{ff}$.

${ }^{14}$ Karl O. Christiansen, Mogens Moe \& Leif Senholtt m.fl.: Effektiviteten af forvaring og særfængsel m.v., Betænkning nr. 644/1972.

${ }^{15}$ Britta Kyvsgaard: Kriminalforsorg i frihed, 1998, er en ny og spændende undersøgelse af holdninger og vurderinger hos de tilsynsundergivne - betinget dømte og prøveløsladte - og forsorgsmedarbejderne. Se eksempelvis s. $134 \mathrm{f}$ om klienternes og de tilsynsførendes vurdering af tilsynets recidivnedsættende virkninger.

${ }^{16}$ Straffelovrådets betænkning om samfundstjeneste s. 90 ff og 98 (også om andre kriminalitetstyper).

${ }^{17}$ Se hertil Alternativer til frihedsstraf (Bet. nr. 806/1977) s. 109, Straffelovrådets betænkning om samfundstjeneste (Bet. nr. 1211/1990) s. 102 ff, justitsministerens lovforslag af 13. oktober 1999, Folketingstidende 1999-2000 tillæg A.

${ }^{18}$ Kriminalforsorgens Årsberetning 1998 s. 44.

${ }^{19}$ Kriminalforsorgens Årsberetning 1997 s. 20 f.

Adresse: Åmosebakken 8, DK-2830 Virum 